\title{
Development of E-Commerce on Flight Ticket Sales (E-Ticketing)
}

\author{
A Sucipto ${ }^{1}, \mathrm{~S}$ Wiganepdo ${ }^{2}$ \\ \{ adesucipto@mahasiswa.unikom.ac.id $^{1}{ }^{1}$, swiganepdo@email.unikom.ac.id ${ }^{2}$ \} \\ Faculty of Engineering and Computer Science, Universitas Komputer Indonesia, Indonesia ${ }^{1}$, \\ Department of Management, Universitas Komputer Indonesia, Indonesia ${ }^{2}$
}

\begin{abstract}
The purpose of this research is to find out the development of e-commerce in terms of e-ticketing and its benefits. This study uses a descriptive method, aiming to display a picture of the situation related to several variable situations. The results of this study are to determine the extent of e-commerce development in e-ticketing and also the benefits gained by ecommerce technology. This research was conducted by discussing the search system, purchases and also payments using e-commerce technology. The results of this study indicate that the application of e-commerce technology is very helpful in terms of purchasing airline tickets online.
\end{abstract}

Keyword : E-commerce, Technology, Application

\section{Introduction}

Transportation tools such as airplanes are used by many people to travel between regions, cities and even countries. Therefore, many companies try to do business in selling airline tickets online. The internet is an information medium used by almost all institutions, organizations, businesses, and individuals in introducing or promoting products or services [1]. At present the internet is one of the conveniences that can be used anywhere to find information even in the case of transactions. Through the internet, people can buy airline tickets without having to go directly to the airline's place or agent.

In understanding the key to success for a virtual store, there will have to be important theoretical and practical implications in terms of developing an E-commerce strategy [2]. It is concluded that there are electronics between unsuitable trade rhetoric and the ability of many local businesses. Policymakers may need to take a more local approach to electronic commerce to prevent it from being a threat to the local economy [3]. Airlines are increasingly adopting the internet as a platform to generate new profits for them [4]. Among other products, consumers prefer to order online rather than at airline agents, such as for accommodation and other products and services [5]. Ticket sales online or E-Ticketing is one way for consumers to buy tickets online without having to go to an airline agent. The airline is now web-based, not only as a technology that is useful for obtaining information but also for providing electronic tickets, but also as being transparent and having clear prices [6]. Direct relationships with customers cause airlines to pay more attention to what is desired and what is not desired by customers [7]. Evaluating the quality of the website in previous research has been applied based on three approaches, namely the information system (IS), marketing, and the second mix [8]. E-ticketing 
is a flight ticket booking process conducted online and connected via a website that is available so that the e-commerce process runs completely [9]. The whole system has now been transformed into the Global Distribution System, which is the main idea on travel sites at this time. Also, this system reduces the costs of airline operations and represents computerization and globalization of the air transportation industry [10].

The purpose of this study was to determine the role of e-commerce in online ticket sales and the benefits of e-commerce applications. This study uses a descriptive method to find out the relationship between e-commerce and the benefits of using online ticket sales.

\section{Material and Methods}

This study also uses descriptive methods to find out the variables related to e-commerce and online business, and also uses other research related to the development of e-commerce and online marketing so that it can analyze how much influence e-commerce technology has in the business world.

\section{Results and Discussion}

As the attractiveness of customers to access the webpage in the online business world, airlines or online services that provide online ticket purchases can provide information about their flights. For example, for online sites that sells flight tickets online, it displays the types of airlines available, flight destinations, and attractive price offers. There are two methods of payments which are direct and indirect payments. For indirect payments, there are many examples such as credit cards, transfers, ATMs, whereas direct payments example includes paying through supermarkets that have collaborated with the online site.

Purchases can be made anywhere and anytime according to the wishes of the buyers. For purchases can be accessed through browsing on various types of electronic devices (see Figure 1).

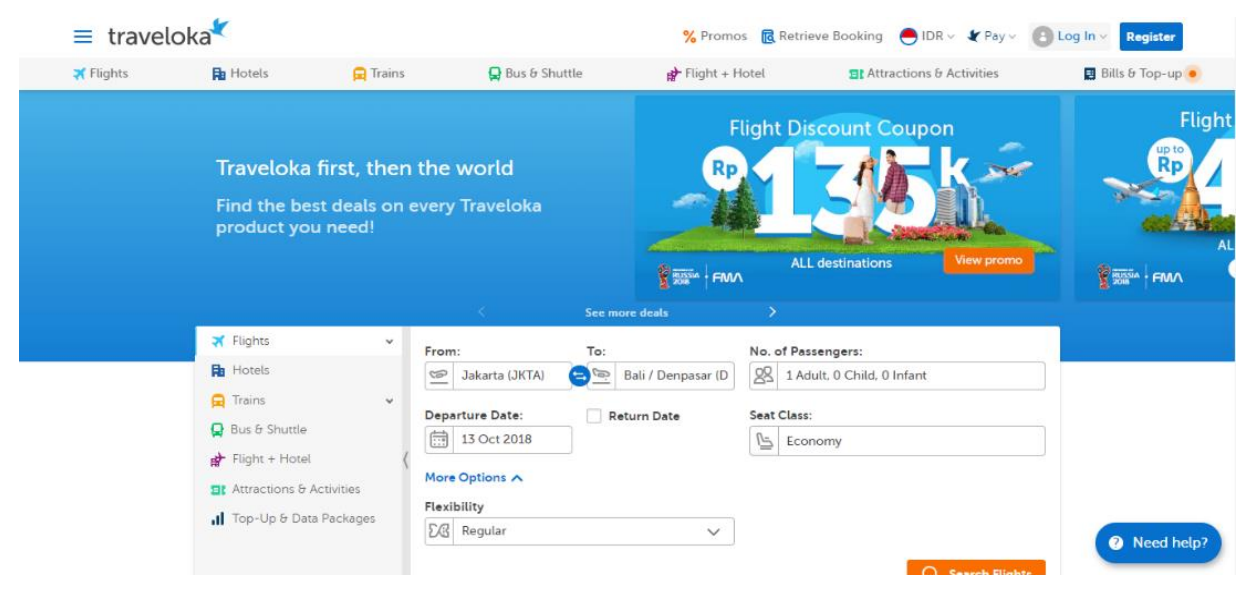

Fig 1. Main View. 
In the main display section there are several menus, language choices, and of course the currency that will be used. In this section, the buyer can create an account and log in with it. For the flight ticket search section, the buyer can determine the desired origin and destination, the date of departure and return, and the number of passengers. Buyers can also determine the desired flight class such as economy, business, and first class. Then it will continue on the available flight list view (see Figure 2).

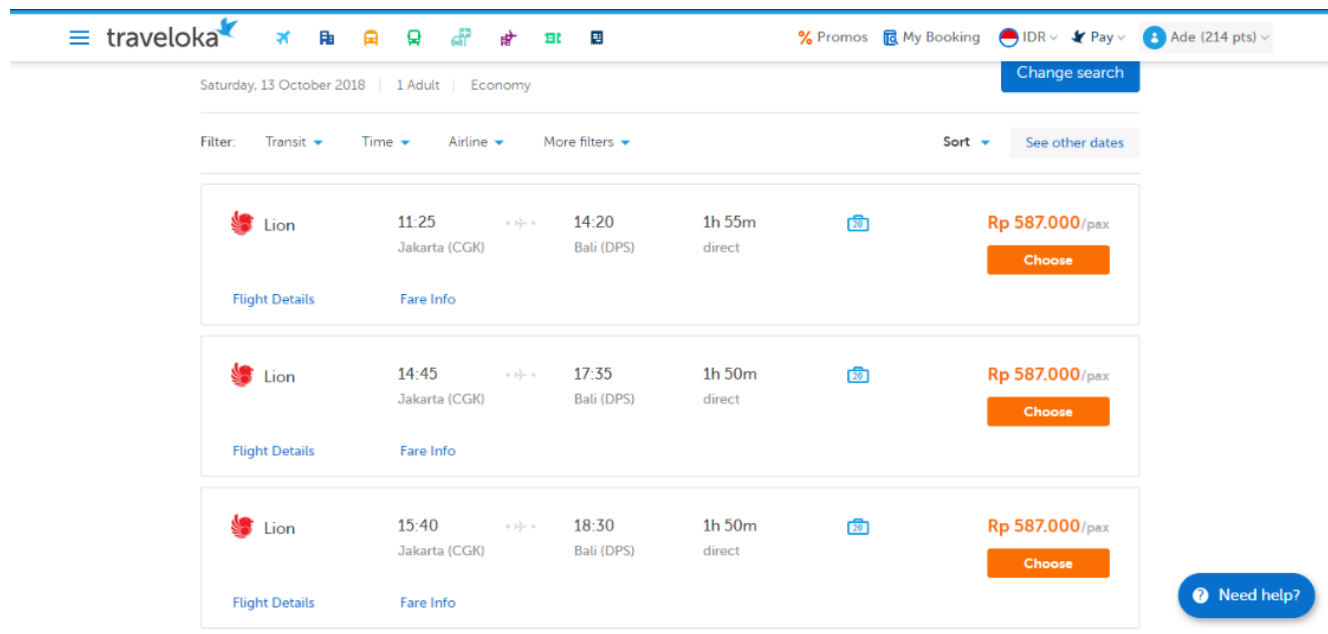

Fig 2. Flight List.

In the flight list view, the flight schedule will be displayed according to what the buyer filled in the previous flight search section. On this display, the buyer can select the desired airline, can see the flight time according to the day that has been chosen, a list of the type of airline, price and facilities received such as the amount of baggage permitted, and food that may be provided by the airline. After the buyer chooses the desired airline, it will proceed to the passenger filling view (Figure 3).

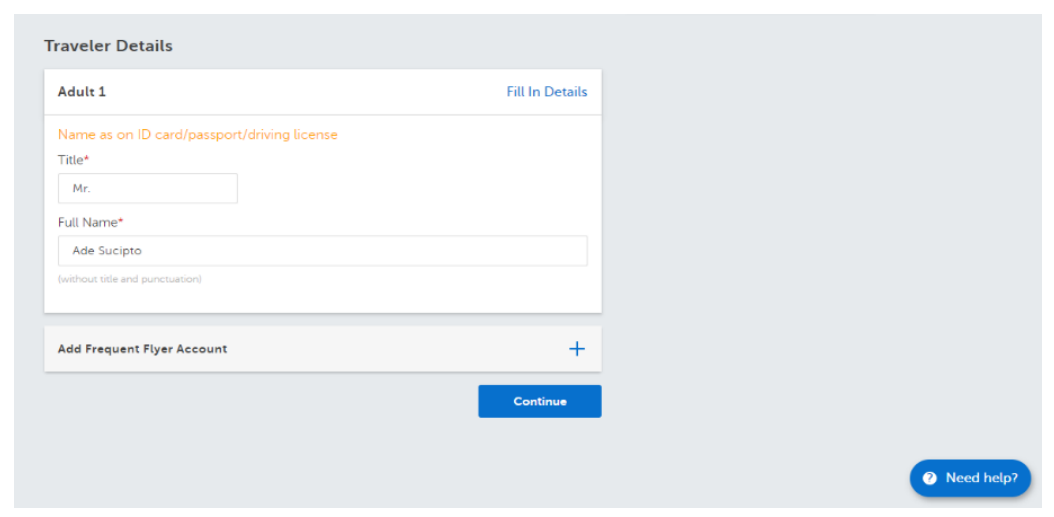

Fig 3. Fill in Passenger Data. 
After the buyer chooses the airline to be used, they proceed to the passenger data filling section. In this section, the buyer will fill in the Title and Full name as shown above. If the data that is filled in is correct, it will proceed to the next menu (see Figure 4).

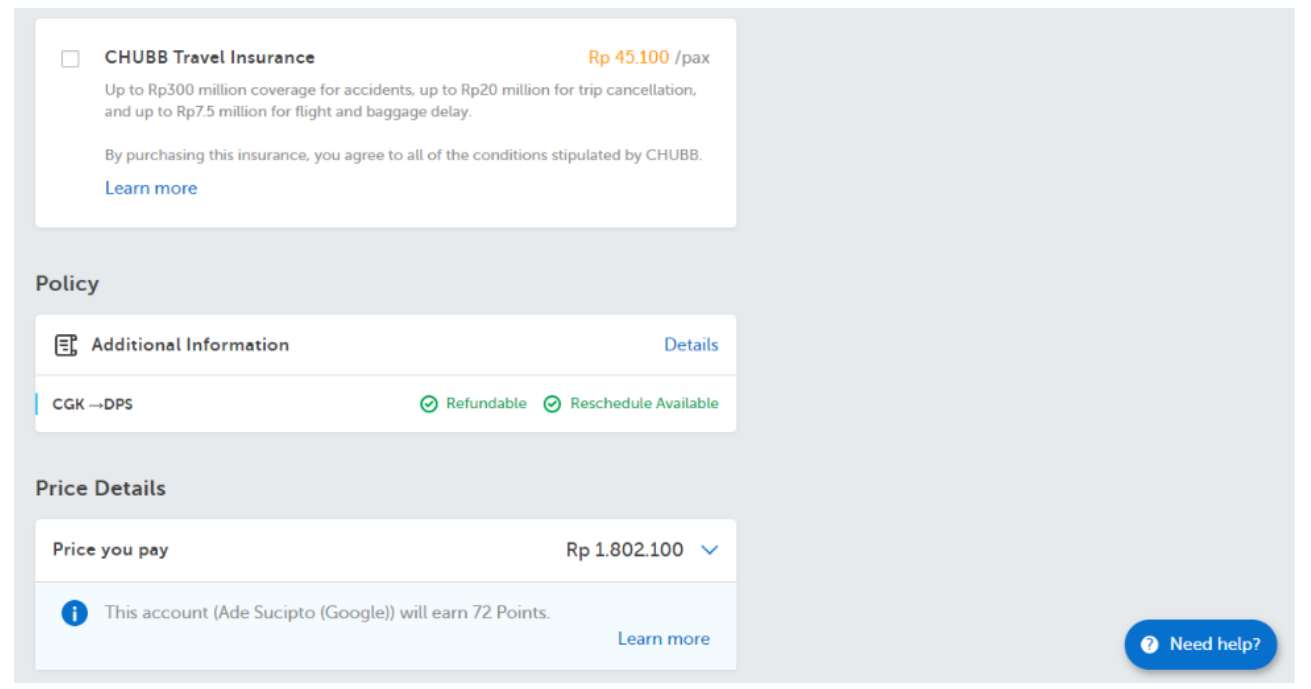

Fig 4. Passenger Data Display.

In this view the buyer will check the data that has been filled. In addition to displaying data, buyers can also opt to use insurance or not. If the buyer uses the insurance provided, the amount of payment will increase. When finished with this display, the buyer will continue on to the payment view (see Figure 5).
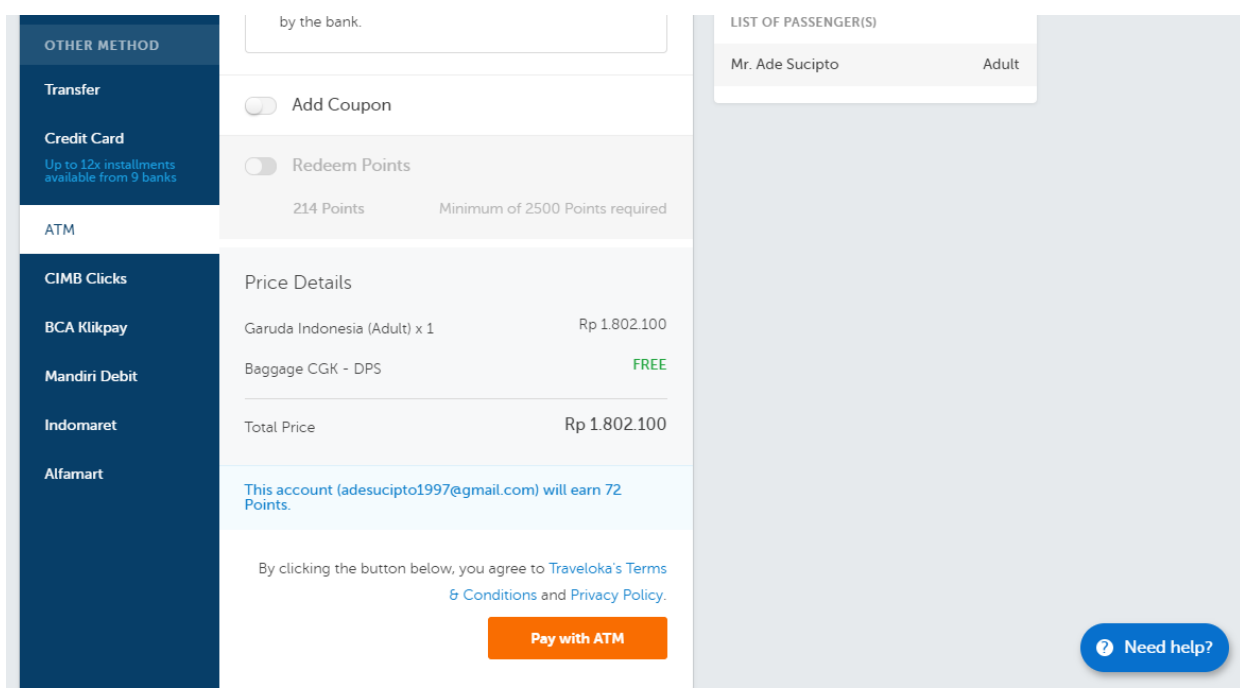

Figure 5. Payment 
In the payment view, the payment method that the buyer will use and the amount that the buyer must pay will be shown. After continuing with the method, if the buyer will proceed to the final view (see Figure 6).

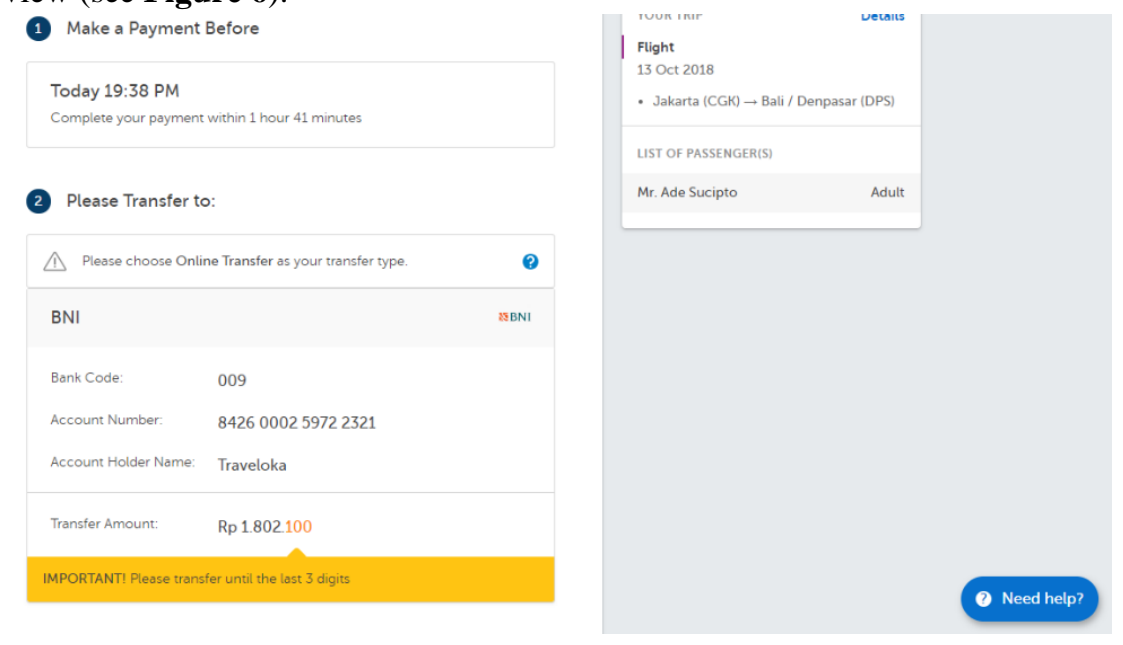

Fig 6. Final View.

In this view the buyer will be informed of the maximum payment time, the amount to be paid, and account information to be addressed. After the buyer makes payment according to the information, they get the flight ticket that has been paid in the form of E-ticketing.

\section{Conclusion}

Technological developments at the present time provide convenience for people, especially in terms of purchasing tickets online without having to make purchases on the spot and do not have to wait long just to use the internet. With e-commerce, consumers will feel comfortable in making transactions due to its ease.

\section{References}

[1] Soeryanto Soegoto, Eddy., : Entrepreneurship Menjadi Pembisnis Ulung,(Jakarta: PT Gramedia), h.506. (2014).

[2] Chen, L. D., \& Tan, J. : Technology Adaptation in E-commerce:: Key Determinants of Virtual Stores Acceptance. European Management Journal, 22(1), 74-86 (2004).

[3] Steinfield, C., Mahler, A., \& Bauer, J. : Electronic commerce and the local merchant. Electronic Markets, 9(1-2), 51-57 (1999).

[4] Harison, E., \& Boonstra, A., : Reaching new altitudes in e-commerce: Assessing the performance of airline websites. Journal of Air Transport Management, 14(2), 92-98 (2008).

[5] Morrisonn, A. M., Jing, S., O'Leary, J. T., \& Cai, L. A. : Predicting usage of the Internet for travel bookings: An exploratory study. Information Technology \& Tourism, 4(1), 15-30 (2001). 
[6] Yu, S. F. : Price perception of online airline ticket shoppers. Journal of Air Transport Management, 14(2), 66-69 (2008).

[7] Chen, F. Y., \& Chang, Y. H. : Examining airline service quality from a process perspective. Journal of Air Transport Management, 11(2), 79-87 (2005).

[8] Anderson, E. W., \& Sullivan, M. W. : The antecedents and consequences of customer satisfaction for firms. Marketing science, 12(2), 125-143 (1993).

[9] Kinanti, F., \& Baridwan, Z. : Analisis Determinan Sistem Informasi E-Ticketing: Pendekatan Extended Theory Of Planned Behaviour. Jurnal Ilmiah Mahasiswa FEB, 1(1). (2012).

[10] Shon, Z. Y., Chen, F. Y., \& Chang, Y. H. : Airline e-commerce: the revolution in ticketing channels. Journal of Air Transport Management, 9(5), 325-331 (2003). 